\title{
Neurological symptoms in tricolor sharkminnow Balantiocheilos melanopterus associated with Myxobolus balantiocheili n. sp. infecting the central nervous system
}

\author{
Arne Levsen ${ }^{1, *}$, Tor Alvik ${ }^{2}$, Sindre Grotmol ${ }^{2}$ \\ ${ }^{1}$ National Institute of Nutrition and Seafood Research, PO Box 176, 5804 Bergen, Norway \\ ${ }^{2}$ Department of Zoology, University of Bergen, Allégaten 41, 5007 Bergen, Norway
}

\begin{abstract}
A new species, Myxobolus balantiocheili, is described from the central nervous system of wild and cultured tricolor sharkminnow Balantiocheilos melanopterus from Thailand. The infection was associated with emaciation and severe neurological symptoms, including sudden uncoordinated darting, rolling and pitching. Whitish cysts of varying shape, measuring 70 to $500 \mu \mathrm{m}$, were located in the brain, spinal cord and in the meninx, and were sometimes accompanied by haemorrhages. In the brain, most cysts were located in the medulla oblongata and the mesencephalon. Cysts with a segmental distribution were observed in the meninx of the spinal cord. Single di- to hexasporic pansporoblasts, and free mature spores, were frequently seen in both the white and grey matter of the brain and spinal cord, mostly associated with blood vessels. Mature spores varied in shape from oval to ellipsoid, measuring $12.3 \pm 0.59$ (range 10.6 to 13.3$) \times 10.0 \pm 0.47$ (9.2 to 10.9$) \times 6.9 \pm 0.20(6.7$ to 7.1) $\mu \mathrm{m}$. Spore size and morphology, in addition to fish-host species and apparently narrow tissue tropism, clearly distinguishes this new Myxobolus. No marked inflammatory response or gliosis was associated with the lesions, but compression and degeneration of the nervous tissue surrounding large cysts was observed. We suggest that the high temperature of the fish hosts' tropical habitat may have increased the rate of development and the virulence of $M$. balantiocheili.
\end{abstract}

KEY WORDS: Tricolor sharkminnow $\cdot$ Balantiocheilos melanopterus $\cdot$ Myxobolus balantiocheili New species $\cdot$ Description $\cdot$ Central nervous system $\cdot$ Pathology $\cdot$ Thailand

\section{INTRODUCTION}

Among the myxobolid parasites from the central nervous system (CNS) of teleost fishes, 7 species have been identified as being the primary cause of neurological disease and spinal deformities: Myxobolus buri in Japanese yellowtail (Egusa 1985), M. cephalis in South Floridan mullet (Iversen et al. 1971), M. drjagini in Chinese silver carp (Wu et al. 1975), M. encephalicus in common carp in Europe (Dykova et al. 1986, Dykova \& Lom 1988), M. sandrae in Scottish perch (Lom et al. 1991), M. spinacurvatura in Japanese mullet (Maeno et al. 1990) and Myxobolus sp. in Australian sandflathead (Rothwell \& Langdon 1990). In the present paper we describe a new Myxobolus species from the central nervous system of the tricolor sharkminnow Balantiocheilos melanopterus (Bleeker, 1851) causing severe neurological symptoms.

Balantiocheilos melanopterus occurs naturally in slow running waters on the Indo-Chinese Peninsula, including the Malay Peninsula, and several islands of the Indonesian archipelago. Due to its popularity as an aquarium fish, many populations have been severely overexploited for the past 2 to 3 decades. As a result, $B$. melanopterus has become locally extinct in many of its endemic areas and, consequently, it is now classi- 
fied as an endangered species (see IUCN Red List, available at www.redlist.org). However, until recently, wild sharkminnows from Thailand were still available to hobbyists worldwide, including Norway. In order to diminish the risk of further overexploitation while still meeting demand, B. melanopterus is now successfully bred in captivity and, hence, the present day trade in this species is based almost entirely on cultured specimens (Ng \& Tan 1997).

\section{MATERIALS AND METHODS}

A total of 18 Balantiocheilos melanopterus were autopsied in August 1992 ( $\mathrm{n}=5)$, March 1994 ( $\mathrm{n}=2$ ), April 1996 ( $\mathrm{n}=8$ ) and May 1996 ( $\mathrm{n}=3)$, respectively. All fish were juveniles, 45 to $74 \mathrm{~mm}$ long (fork length), except for 2 adults examined in March 1994, which measured 150 and $156 \mathrm{~mm}$, respectively. The fish originated from wild or cultured populations in Thailand and were either submitted to our laboratory by a Norwegian wholesaler of ornamental fish $(n=10)$, or were obtained from a local pet shop in Bergen, Norway $(n=8)$. All fish were moribund upon arrival at the laboratory, and all showed disease symptoms including abnormal swimming and emaciation.

Following gross pathological examination of the fish, fresh tissue smears from the viscera, heart and CNS were microscopically searched for spores and vegetative stages of Myxobolus. After exposing the brain by removing the cranium roof under a dissecting microscope, the in situ appearance of cysts situated on or just below the meninx was recorded. Both free spores and spores obtained from cysts were measured and described according to Lom \& Arthur (1989). Drawings were based on spores mounted in glycerol gelatine. Spore dimensions are expressed as mean length \pm SD (range) $\times$ mean width $\pm \mathrm{SD}$ (range) $\times$ mean thickness $\pm \mathrm{SD}$ (range).

For histopathological investigations, various parts of the CNS, or whole heads from 6 juvenile fish with severe neurological symptoms, were fixed in a cold neutral-buffered $4 \%$ formaldehyde and $5 \%$ glutaraldehyde solution (Karnovsky's fixative). After dehydration in an ethanol series, the samples were embedded in metachrylate resin, sectioned at 5 to $6 \mu \mathrm{m}$ and stained in $1 \%$ methylene blue. Additionally, tissue samples from kidney, spleen, liver and gall bladder of 2 heavily infected fish were searched histologically for extrasporogonic stages of the parasite. For scanning electron microscopy (SEM), cysts were removed from the brain of 2 heavily infected fish, crushed in physiological saline in test tubes, and washed and centrifuged to obtain masses of spores. They were then fixed in Karnovsky's fixative, postfixed in $1 \%$ buffered
$\mathrm{OsO}_{4}$, dehydrated, critical-point dried, placed on stubs and coated with a gold-palladium mixture.

\section{RESULTS}

\section{Symptoms and gross pathology}

All the examined fish $(\mathrm{n}=18)$ were infected with Myxobolus. The fish received in August 1992, March 1994 and May 1996 displayed lethargy and neurological symptoms related to loss of equilibrium and/or the coordination of movement. These symptoms typically comprised sudden uncoordinated darting, rolling and pitching. All were strongly emaciated. In the fish of the latter shipment, haemorrhages on the dorso-posterior part of the hind brain were clearly visible through the cranial roof. Upon dissection of the cranial cavity, whitish cysts of varying shape and size were found at various sites on the surface of the brain.

\section{Description of Myxobolus balantiocheili n. sp.}

- Host: wild or cultured tricolor sharkminnow Balantiocheilos melanopterus (Bleeker, 1851) (Cyprinidae)

- Locality: Thailand, natural freshwater bodies or culturing facilities

- Site of infection: central nervous system, meninx and tissue surrounding the vertebrae

\section{Vegetative stages}

Macroscopically visible cysts were loosely attached to the surface of the brain and spinal cord, consisting of single or, sometimes, multiple polysporous plasmodia. Most cysts were oval to spherical, measuring between 70 and $500 \mu \mathrm{m}$ in cross-section. The largest cyst found, approximately $600 \mu \mathrm{m}$ in diameter, was irregular in shape with some smaller plasmodia forming lobes on the outside (Fig. 1).

\section{Spores}

Mature spores $(n=50)$ varied in shape from oval to ellipsoid in frontal view (Fig. 2), measuring $12.3 \pm 0.59$ (range 10.6 to 13.3$) \times 10.0 \pm 0.47(9.2$ to 10.9$) \times 6.9 \pm$ 0.20 (6.7 to 7.1) $\mu \mathrm{m}$. Neither sutural edge markings nor spore projections were present. A mucous envelope or distinct iodinophilous vacuole was absent. The shell valves were smooth, with multiple spherical, flat elevations on the surface (Fig. 3). A prominent triangular intercapsular process was present. Polar capsules were 


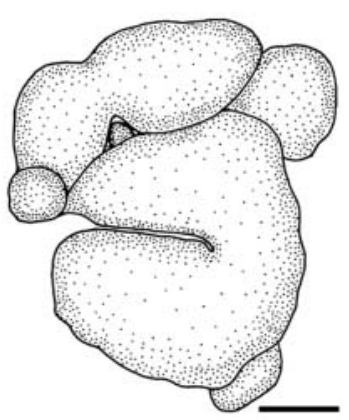

Fig. 1. Myxobolus balantiocheili n. sp. Line drawing of a cyst from the surface of the hind brain. Note the lobes, each constituting a separate plasmodium. Scale bar $=100 \mu \mathrm{m}$

pyriform and of equal size, $5.7 \pm 0.39$ (4.9 to 6.7$) \mu \mathrm{m}$ long and $3.6 \pm 0.25$ (3.1 to 4.1) $\mu \mathrm{m}$ wide. Each polar filament had 6 to 8 tightly coiled turns, roughly perpendicularly to the longitudinal axis of the capsule. The openings of the polar capsules were set close together and opened at the anterior margin of the spore (Fig. 4). There were no differences in spore dimensions (length and width) in relation to infection site, i.e. whether they originated in the brain, spinal cord or kidney (2-sided $t$-test, $\mathrm{p}<0.05$ for all groups).

\section{Histopathology}

Extrasporogonic stages were not observed. Single di- to hexasporic pansporoblasts and free mature spores were frequently seen in both the white and grey matter of the brain and spinal cord. They were mostly associated with arteries and veins (Figs. 5 to 7), but also with smaller blood vessels. Single pansporoblasts and early plasmodia containing a few pansporoblasts
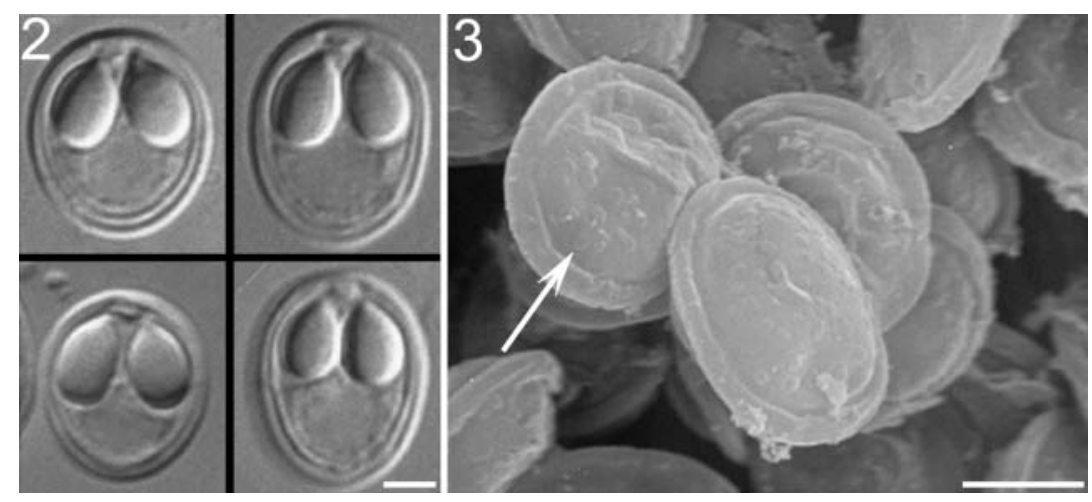

Figs. 2 \& 3. Myxobolus balantiocheili n. sp. Micrographs of mature spores. Fig. 2. Differential interference contrast microscopy of 4 free spores. Note the variation in spore morphology. Scale bar $=3 \mu \mathrm{m}$. Fig. 3. Scanning electron microscopy of spores from plasmodia. Note the smooth shell valves with multiple spherical, flat elevations (arrow). Scale bar $=6 \mu \mathrm{m}$ were also found in the choroid plexuses and in the meninx. Infection of the retina was not observed. Free spores also occurred in the kidney and spleen associated with melanomacrophage centres. Occasionally, free spores were detected in the vitreous body of the eyes, and, in one heavily infected fish, in the lumen of the heart ventricle. Cysts consisting of 1 to multiple polysporous plasmodia, surrounded by a thin capsule of fibroblasts and collagen (Fig. 8), were multifocally distributed in the brain and spinal cord (Figs. 8 to 10). Most plasmodia contained numerous peripherally situated pansporoblasts, indicating an early stage of development. Cysts were frequently associated with the meninx, or found in nervous tissue in close proximity to the meninx (Fig. 9). In the brain, most cysts were located in the medulla oblongata and in the floor of the ventriculus mesencephali (Fig. 10). Segmentally distributed cysts associated with the meninx were found between the vertebral bodies and the spinal cord (Fig. 11), sometimes extending deeply into the nervous tissue (Fig. 12). In some cases, these cysts were large and had invaded the tissue and cavities surrounding entire vertebrae. Neither marked inflammatory response nor gliosis were associated with the lesions, but compression and degeneration of the nervous tissue surrounding large cysts was observed. In the spinal cord, severe compression of nervous tissue was frequent around voluminous cysts (Fig. 12).

\section{DISCUSSION}

Most species of Myxobolus cannot be precisely distinguished on the basis of spore shape and size alone. Thus, additional morphological characteristics as suggested by Lom \& Arthur (1989) are equally important. Moreover, the tendency of myxosporidia to be host, organ and tissue specific (Molnar 1994) should also be considered when classifying new species. In Myxobolus, however, spore morphology seems to be a more reliable species character compared to host specificity and tissue tropism (Salim \& Desser 2000). Hence, the myxobolids from the CNS of other cyprinid fishes, i.e. $M$. cybinae, $M$. drjagini, $M$. encephalicus, $M$. filamentosus and $M$. hendricksoni, all differ from $M$. balantiocheili with respect to spore size and morphology as well as size, shape and relative position of the polar capsules (Mitenev 1971, Wu et al. 1975, Haldar et al. 1981, Shulman 1984, Mitchell et al. 1985, Dykova et al. 1986, Lom \& Dykova 1992). 


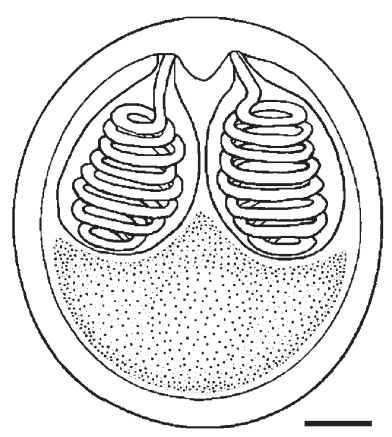

Fig. 4. Myxobolus balantiocheilin. sp. Line drawing of a mature spore in frontal view. Scale bar $=2 \mu \mathrm{m}$

The fish host of Myxobolus balantiocheili is endemic to tropical habitats in Southeast Asia, while the other Myxobolus species, except of M. filamentosus, are reported from temperate or even subarctic regions. The taxonomic significance of comparing species from such different geographic and climatic regions may be limited. $M$. filamentosus, on the other hand, is described from the meninx of the brain in blackspot barb Puntius filamentosus from West Bengal, India. The blackspot barb seems to be sympatric with B. melanopterus in northern Thailand (www. fishbase.org). Although the tricolor sharkminnow is a popular ornamental fish, its parasites, including myxosporidian species, appear to be unknown. Some myxobolids that are described from sympatric barb species, i.e. M. barbi from ticto barb (Tripathi 1953), M. karnatakae from swamp barb (Hagargi \& Amoji 1981) and M. sophorae from pool barb (Jayasri 1982) do not, however, occur in the CNS of their hosts. More importantly, they all differ from $M$. balantiocheili in spore size and/or morphology. Thus, based on the distinctive spore characteristics, apparently narrow organ specificity, and consideration of the Myxobolus parasites from sympatric barbs, we regard $M$. balantiocheili a new species.

Pansporoblasts and mature, spore-containing, plasmodia of Myxobolus balantiocheili showed a strong
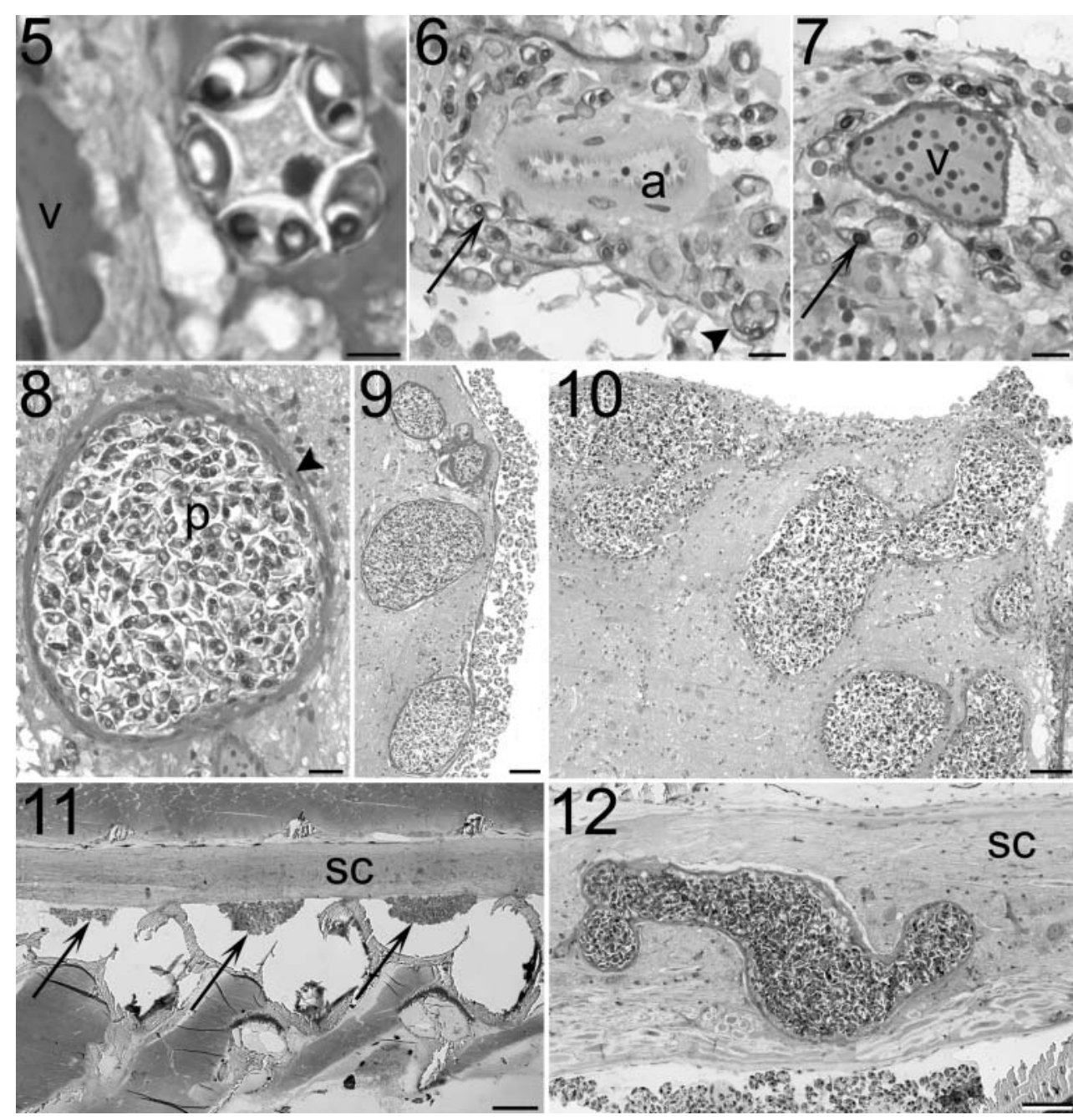

Figs. 5 to 12. Balantiocheilos melanopterus infected with Myxobolus balantiocheili $\mathrm{n}$. sp. Central nervous system of semi-thin sections of metachrylate embedded tissue stained in methylene blue. Fig. 5. Hexasporic pansporoblast associated with a vein $(v)$ in the medulla oblongata. Scale bar $=5 \mu \mathrm{m}$. Fig. 6 . Artery (a) of the mesencephalon with pansporoblasts and numerous spores in the adventitia and surrounding tissue (arrow). Scale bar $=10 \mu \mathrm{m}$. Fig. 7 . Vein (v) in the medulla oblongata with spores in the adventitia and surrounding tissue (arrow). Scale bar $=10 \mu \mathrm{m}$. Fig. 8. Plasmodium (p) in the medulla oblongata, surrounded by a capsule of fibroblasts and collagen (arrowhead). Scale bar $=10 \mu \mathrm{m}$. Fig. 9. Multiple plasmodia in the superficial grey matter of the medulla oblongata and associated meninx. Scale bar $=50 \mu \mathrm{m}$. Fig. 10. Large cysts consisting of multiple plasmodia in the mesencephalon. The lumen is the ventriculus mesencephali. Scale bar $=50 \mu \mathrm{m}$. Fig. 11. Spinal cord (sc) with multiple plasmodia (arrows) associated with the meninx, and arranged segmentally on the dorsal surface of the vertebral centres. Scale bar $=200 \mu \mathrm{m}$. Fig. 12 . Cyst in the spinal cord (sc) consisting of multiple plasmodia, displacing and compressing the nervous tissue. Scale bar $=50 \mu \mathrm{m}$ 
affinity to tissues of the CNS associated with blood vessels in, or in close proximity to, the meninx. The large, macroscopically visible cysts on the surface of the brain and spinal cord most probably developed from the meninx. This seems equally to be the case for cysts that were observed between the vertebral bodies and the meninx of the spinal cord. Hence, we basically consider the species to be specific to the CNS, with high affinity to meningal tissue.

Contrary to our observations on sharkminnow, neurological symptoms have not been associated with other brain infecting myxobolids in fish, e.g. Myxobolus cotti, M. galaxii, M. hendricksoni and M. neurophilus (Mitchell et al. 1985, Lom et al. 1989, ElMatbouli et al. 1990, Langdon 1990, Dzulinsky et al. 1994). Common to these species is their ability to infect the CNS without inducing severe inflammation, even at high intensities. The nervous tissue of teleosts has the ability to regenerate through production of new neurons (Zupanc \& Horschke 1995). Thus, when the plasmodial growth rate is slow, the nervous tissue may adapt, and the infection may progress subclinically. At high plasmodial growth rate, however, the ability of the host to compensate may be insufficient, and neurological symptoms may appear. Our findings of numerous plasmodia in the sporogenic phase may indicate that the infection was at an early stage, and that the plasmodial growth rate was high. Little is known about the influence of water temperature on the myxosporidian multiplication rate and virulence in fish. However, mortalities and morbidities due to Myxidium sp. in experimentally infected tiger puffer Takifugu rubripes were apparently promoted by higher water temperatures (Yasuda et al. 2002). Thus, the observed hemorrhages in the present study may indicate a virulent course of infection due to a massive and persistent neuroinvasion of multiplication stages of penetrated triactinomyxon sporoplasms. Hence, the constantly high temperature of the tropical habitat of the sharkminnow may contribute to the apparently high virulence, as compared to that of other brain infecting Myxobolus species that occur in temperate regions.

\section{LITERATURE CITED}

Dykova I, Lom J (1988) Review of pathogenic myxosporeans in intensive culture of carp (Cyprinus carpio) in Europe. Folia Parasitol 35:289-307

Dykova I, Lom J, Cirkovic M (1986) Brain myxoboliasis of common carp (Cyprinus carpio) due to Myxobolus encephalicus. Bull Eur Assoc Fish Pathol 6:10-11

Dzulinsky K, Cone DK, Faulkner GT, Cusack R (1994) Development of Myxobolus neurophilus (Guilford, 1963) (Myxosporea) in the brain of yellow perch (Perca flavescens) in Vinegar Lake, Nova Scotia. Can J Zool 72: $1180-1185$
Egusa S (1985) Myxobolus buri sp. n. (Myxosporea: Bivalvulida) parasitic in the brain of Seriola quinqueradiata Temminck et Schlegel. Fish Pathol 19:239-244

El-Matbouli M, Fischer-Scherl T, Hoffmann RW (1990) Light and electron microscopic studies on Myxobolus cotti El-Matbouli and Hoffmann, 1987 infecting the central nervous system of the bullhead (Cottus gobio). Parasitol Res 76:219-227

Hagargi SS, Amoji SD (1981) Myxosoma karnatakae n. sp. (Protozoa: Myxosporidia) from the caudal muscles of the freshwater teleost fish Barbus chola (Ham. et Buch.). Arch Protistenk 124:385-390

Haldar DP, Mukherjee M, Kundu TK (1981) Observations on two new species of Myxosoma Thélohan, 1892 (Myxozoa: Myxosomatidae) from freshwater teleost fishes. Arch Protistenkd 124:244-251

Iversen ES, Chitty N, Van Meter NN (1971) Some myxosporidia from marine fishes in South Florida. J Protozool 18:82-86

Jayasri M (1982) Morphology and pathology of Myxobolus sophorae n. sp. Proc Indian Acad Parasitol 3:1-3

Langdon JS (1990) Observations on new Myxobolus species and Kudoa species infecting the nervous system of Australian fishes. J Appl Ichthyol 6:107-116

Lom J, Arthur JR (1989) A guideline for the preparation of species descriptions in Myxosporea. J Fish Dis 12:151-156

Lom J, Dykova I (1992) Protozoan parasites of fishes. Developments in Aquaculture and Fisheries Science: 26. Elsevier, Amsterdam

Lom J, Feist SW, Dykova I, Kepr T (1989) Brain myxoboliasis of bullhead, Cottus gobio L., due to Myxobolus jiroveci sp. nov.: light and electron microscope observations. J Fish Dis 12:15-27

Lom J, Pike AW, Dykova I (1991) Myxobolus sandrae Reuss, 1906, the agent of vertebral column deformities of perch Perca fluviatilis in northeast Scotland. Dis Aquat Org 12: $49-53$

Maeno Y, Sorimachi M, Ogawa K, Egusa S (1990) Myxobolus spinacurvatura sp.n. (Myxosporea: Bivalvulida). Fish Pathol 25:37-41

Mitchell LG, Seymour CL, Gamble JM (1985) Light and electron microscopy of Myxobolus hendricksoni sp. nov. (Myxozoa: Myxobolidae) infecting the brain of the fathead minnow, Pimephales promelas Rafinesque. J Fish Dis 8: $75-89$

Mitenev VK (1971) New and little known species of myxosporidians from fishes of the Kola Peninsula. Parazitologiya 5:556-558 (in Russian)

Molnar K (1994) Comments on the host, organ and tissue specificity of fish myxosporeans and on the types of their intrapiscine development. Parasit Hung 27:5-20

Ng PKL, Tan HH (1997) Freshwater fishes of Southeast Asia: potential for the aquarium fish trade and conservation issues. Aquar Sci Conserv 1:79-90

Rothwell JT, Langdon JS (1990) Spinal curvature associated with Myxobolus sp. cysts in the brain of sandflathead (Platycephalus bassensis L.). J Appl Ichthyol 6:244-246

Salim KY, Desser SS (2000) Descriptions and phylogenetic systematics of Myxobolus spp. from cyprinids in Algonquin Park, Ontario. J Eukaryot Microbiol 47:309-318

Shulman SS (1984) Parasitic protozoa, Vol. 1. In: Bauer ON (ed) A key to the parasites of freshwater fishes of the USSR (in Russian). Nauka, Leningrad

Tripathi YR (1953) Studies on parasites of Indian fishes, I. Protozoa Myxosporidia together with a check list of parasitic protozoa described from Indian fishes. Rec Ind Mus, Calcutta 50:63-88 
Wu B, Chang ZH, Chang J, Chen YS (1975) Twist disease of Hypophthalmichthys molitrix in Hangzhou Region of Chekiang Province. Acta Zool Sin 21:190-198

Yasuda H, Ooyama T, Iwata K, Tun T, Yokoyama H, Ogawa K (2002) Fish-to-fish transmission of Myxidium spp. (Myxo-

Editorial responsibility: Wolfgang Körting,

Hannover, Germany zoa) in cultured tiger puffer suffering from emaciation disease. Fish Pathol 37:29-33

Zupanc GKH, Horschke I (1995) Proliferation zones in the grains of adult gymnotiform fish - a quantitative mapping study. J Comp Neurol 353:213-233

Submitted: May 12, 2003; Accepted: September 2, 2003

Proofs received from author(s): March 24, 2004 